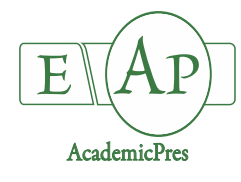

Schirone B et al. (2021)

Notulae Botanicae Horti Agrobotanici Cluj-Napoca

Volume 49, Issue 2, Article number 12325

DOI: $10.15835 /$ nbha49212325

Research Article

\title{
A proposal for modifying coppicing geometry in order to reduce soil erosion in the forest areas
}

\author{
Bartolomeo SCHIRONE ${ }^{1 *}$, Pietro SALVANESCHI ${ }^{1}$, Kevin \\ CIANFAGLIONE ${ }^{2}$, Massimo PECCI ${ }^{3}$, Teodoro ANDRISANO ${ }^{4}$, \\ Federico VESSELLA ${ }^{1}$, Andrea PETROSELLI ${ }^{5}$
}

\author{
${ }^{1}$ Tuscia University, Department of Agriculture and Forest Sciences (DAFNE), San Camillo del Lellis s.n.c., O1100 Viterbo, \\ Italy; schirone@unitus.it ("correspondingauthor); salvaneschi@unitus.it; vessella@unitus.it \\ ${ }^{2}$ Université de Lorraine, Faculté des Sciences et Techniques, UMR UL/AgroParisTech/INRAE 1434 Silva, BP 70239 , \\ CEDEX 54506 Vandoeuvre-lès-Nancy, France; kevin.cianfaglione@univ-lorraine.fr \\ ${ }^{3}$ Department of Regional Affairs and Autonomies (DARA) - Presidency of the Council of Ministers, \\ Via dellaStamperia 8,00186Rome, Italy;m.pecci@palazzochigi.it \\ ${ }^{4}$ Majella National Park, Via Badia 28,67039 Sulmona, Italy; teodoro.andrisano@parcomajella.it \\ ${ }^{5}$ Tuscia University, Department of Economics, Engineering, Society and Business Organisation (DEIM), \\ 01100 Viterbo,Italy; petro@unitus.it
}

\begin{abstract}
A key factor to reduce soil erosion and soil instability is the conservation of forest areas. In the last years, in all Europe, forest logging has increased. The Italian situation is paradigmatic because more than $70 \%$ of the broadleaved forests are managed as coppices and new exploitations concerning biomass for energy production have tripled since 2001. The common coppicing method leaves standards uniformly distributed on the ground, but this geometry has proven to not play an effective role in soil erosion control. In this paper, we propose a different method for coppicing geometry, aimed to decrease the soil erosion risk. In particular, the theoretical framework of the model is presented here, employing the USLE framework and discussing a real case study, while the results of the experimental tests, which are in progress, will be discussed in future papers. The theoretical results seem to demonstrate the method's validity, which is expected to reduce soil erosion amount in the range $29-42 \%$.
\end{abstract}

Keywords: barriers; coppice; mountain slopes; soil erosion; standards

\section{Introduction}

Italy is one of the European countries with the highest value of hydrogeological instability due to natural and anthropogenic causes: more than 300 people died in the last 10 years in Italy due to this problem (Trigila et al., 2018). The hydrogeological risk could become more frequent in the next years because of the climate changes that should modify the precipitation regime, causing an increase of intense rainfall events with a very short duration. From projections of the Regional Climate Models for Europe, in the future, higher rainfall intensities and longer dry periods are generally expected (EEA, 2017). Considering the projections related to a

Received: 29 Mar 2021. Received in revised form: 33 May 2021. Accepted: 28 May 2021. Published online: 04Jun 2021.

From Volume 49, Issue 1, 2021, Notulae Botanicae Horti Agrobotanici Cluj-Napoca journal uses article numbers in place of the traditional method of continuous pagination through the volume. The journal will continue to appear quarterly, as before, with four annual numbers. 
future period in Italy (until 2090), a decrease of the annual cumulative rainfall value, a modest increase of the annual maximum daily rainfall, and a significant increase of the time interval between two consecutive rainfall events should occur (Desiato et al., 2015).

A key factor to reduce soil erosion and hydrogeological instability is the conservation of forest areas, that is the object of this paper. Indeed, it is well known that forests exercise a protective action on soil (Borrelli et al., 2017a). The efficiency of soil protection by forest is due to the forest coverage. In general, every interruption of the forest coverage causes a reduction on the capacity to intercept the rainfall by the tree canopies with a consequent increase of soil erosion. However, this could be mitigated by the adoption of particular silvicultural treatment (Iovino, 2009; Altieri et al., 2018). According to Ceccherini et al. (2020) in the last ten years, in all Europe, logging is increased, with an increase of $49 \%$ for the harvest surface and of $60 \%$ for the biomass exploitation. The mean area of the harvested patch size is becoming bigger; for instance, in Italy the increase reached $+125 \%$, that was the highest value in Europe after Portugal (Ceccherini et al., 2020). The Italian situation must be highlighted because more than $70 \%$ of the broadleaved forests are managed as coppice and new utilizations concerning biomass for energy production are tripled since 2001 (Eurostat, 2020; https://ec.europa.eu/eurostat/web/energy/data/energy-balances). Additionally, the last national policy on forests risks to aggravate the situation, promoting the tampering and the exploitation of forests, rather than encouraging natural dynamics (Bottacci, 2018; Searchinger et al., 2018).

The effects of this forest policy are already evident: in the last years, the area of a single coppicing could reach even 20 ha on very steep slopes, hence it is crucial to mitigate the damages of these larger and more frequent coppicing. Coppice management activities modify indeed the soil structure and the biodiversity affecting the successional processes, reducing progressively the soil quality by a frequent rejuvenation of pedological profiles, and, in general, rapidly increasing the superficial soil erosion due to the frequent cuttings (the rotation period typically is lower than 25 years) (Clauser, 1989; Borrelli et al., 2017b; Vacca et al., 2017). Thinking about that, we should start considering new approaches in coppicing, with the aim to reduce the soil erosion without decreasing biomass production.

The prevalent coppicing method in Italy is the "coppice with standards" and the word "matricinatura" is used to indicate both the number and the type of standards ("matricine" in Italian language) per surface unit. In this work, we will use the term Standards Arrangement (SA) for indicating such system. According to the classic silviculture, the number of standards per hectare is variable, but the range should be between 80 and 120 per hectare (with a minimum of 30 for some species), so that the soil that remains covered after a cut typically does not exceed $10 \%$ of the total area.

Usually, the standards are scattered on the ground (Scattered Standards Method, SSM), although several studies propose alternative solutions to limit the inconveniences of such distribution. For example, the distribution of standards in groups (Grouped Standards Method, GSM) would guarantee a lower impact on the landscape and more ecological benefits, especially for nemoral species (Grohmann et al., 2002).

After a coppice cutting, standards are left mainly because they should be useful to: a) progressively substitute old stumps with plantlets; b) promote the conservation of genetic diversity; c) keep safe soil coverage and reduce soil erosion (Piussi, 2000). Notwithstanding, it has been demonstrated that standards do not significantly play a role in any of those functions, while it has been shown that they depress the generation of new shoots on stumps (Amorini et al., 1998; Bianchi and Giovannini, 2006). Actually, the SSM is the heritage of an old coppicing practice that included the saving of some adult trees useful to guarantee not only firewood but also lumber (Zanzi Sulli and Di Pasquale, 1993).

Despite a frequent occurrence of coppices, Italian studies on relationships between coppicing and soil erosion are scarce. There is a lack of studies about forest coverage before and after a cutting, although soil use is a key factor for methods that aim to estimate the soil erosion. On the contrary, many investigations focus on SA density: the main goal is always the search for the optimal number of standards to be left, according to the target species and local environmental conditions, in order to guarantee the wood production (Corona et al., 1986; La Marca et al., 1987; La Marca et al., 1996). 
Among the authors who studied soil erosion in coppices, Garfi et al. (2006) and Iovino (2007) recommend some actions to limit soil erosion such as:

- To distribute cuttings in space to guarantee continuity.

- To limit the surface cutting width according to slope.

- To increase the time interval between two consecutive cuttings.

- To perform cuttings avoiding an overlap with periods of maximum precipitation.

- To implement some practical procedures to significantly mitigate the impact of coppicing.

In the present paper we aim to explore this last point, not discussed by Iovino (2007), investigating how to reduce soil erosion by modifying the geometry of SA. The novelty of the manuscript is in the presentation of a new method for determining the geometry of coppicing. Here we show the theoretical framework, while an experimental research is already in progress and will be discussed in future papers. The final goal will be to observe how much the model differs from reality. In this way the model could be improved and calibrated using experimental data.

\section{Materials and Methods}

\section{The proposed theoretical model: Bands of standards}

After a cutting, erosion usually occurs inside a forest patch. The erosion is more intense as the patch is longer in the downslope direction, the slope is greater, and the forest cover is diminished (Borrelli et al., 2017a). In view of this, we propose a new method of SA related to coppices located in high slope areas, where, typically, cuttings occur with the longer side parallel to the steepest slope direction.

The proposed method is a coppice with bands of standards (Banded Standards Method, BSM), instead of SSM or GSM (Figure 1). It consists of leaving standards stripes perpendicular to the steepest slope direction, instead of leaving standards that are scattered all over the area. The proposed method aims in creating a barrier for surface runoff. Indeed, after a traditional coppicing, the residual forest cover ranges between $10 \%$ and $20 \%$ and the effect of standards on surface runoff is very limited because of their spread diffusion. The same percentage of standards, but clustered in bands parallel to contour lines, could be more efficient with a positive effect on soil erosion due to the cutting geometry.

\section{Site description}

The study site has been selected due to its representativeness for the Central Apennine forests where there are frequent degraded coppices that should be left to natural evolution and, instead, continue to be regularly cut. The investigated area pertains to Colle Tavola hill (Municipality of Rieti, Figure 2), it is characterized by an average elevation of $970 \mathrm{~m}$, an average slope of $55 \%$, and it is south-east oriented.

Regarding the climate, temperature and rainfall data were retrieved from Colli sul Velino meteorological station, in proximity of the selected area. Bagnouls-Gaussen diagram, shown in Figure 3, defines the climate as typically Mediterranean, with dry summer and rainfall concentrated during autumn. This circumstance is noteworthy because regional laws prescribe that coppicing cuttings to be carried out during autumn and winter periods, i. e. during the vegetation dormant season.

Whit respect to geology, the geomorphological setting of the area is characterized by the outcropping of layers of micritic limestones (Facies Maiolica Auct.), sometimes densely stratified, fractured and weathered, with the presence of a fault, surveyed just few dozen meters downslope and out of the investigated area. Both surface and subsurface runoff flow from the top of Colle Tavola hill in south-east direction, where the fault line and the gully represent, respectively, the permeability threshold/spring of a perched aquifer and the local base level for runoff. The rock mass quality, after a geological-technical survey, can be expressed as "fair" (Beniawski 1976; Amanti and Pecci 1995). 
Schirone B et al. (2021). Not Bot Horti Agrobo 49(2):12325

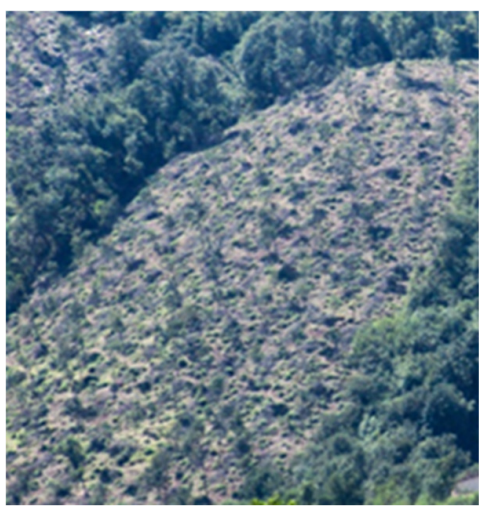

(A)

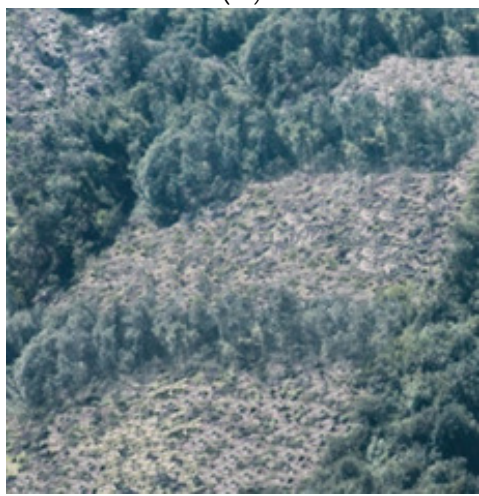

(C)

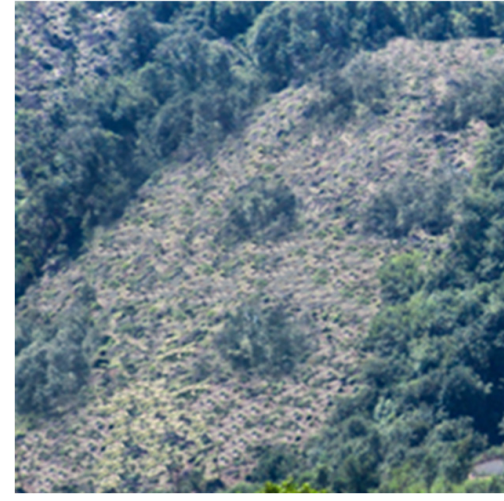

(B)

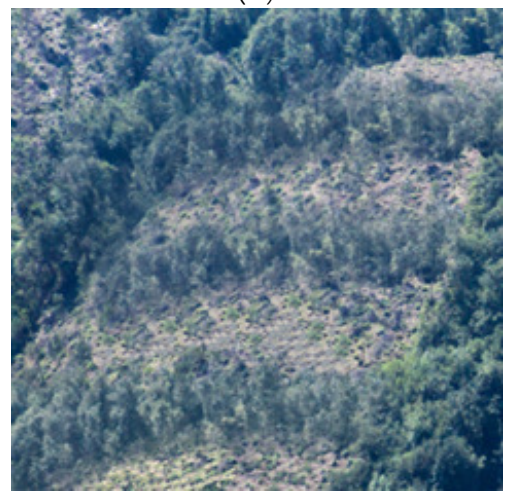

(D)

Figure 1. Rendering of different types of standards arrangement (SA). (A) Coppice with SSM; (B) Coppice with GSM; (C) Coppice with BSM, two bands; (D) Coppice with BSM, three bands

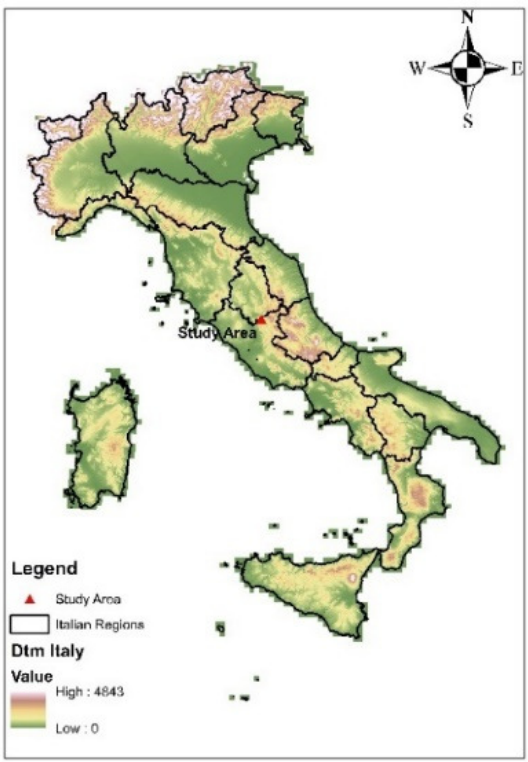

(A)

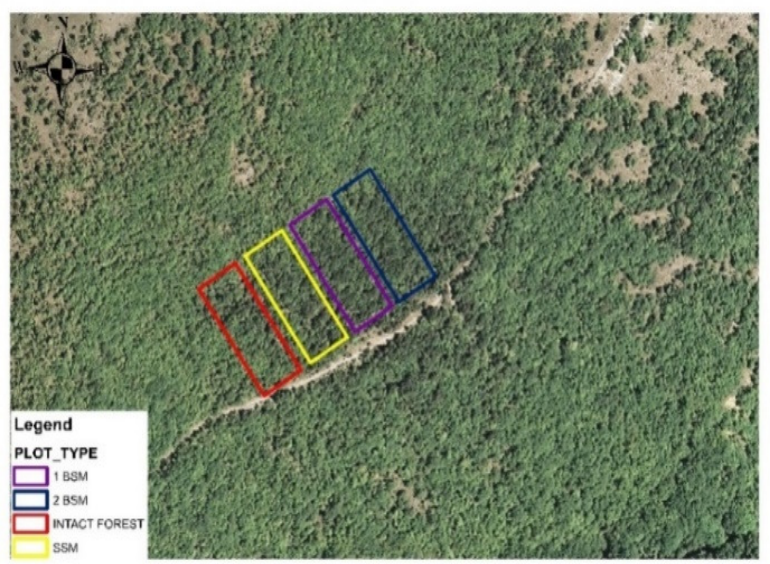

(B)

Figure 2. Study site localization: (A) national level and (B) local level 


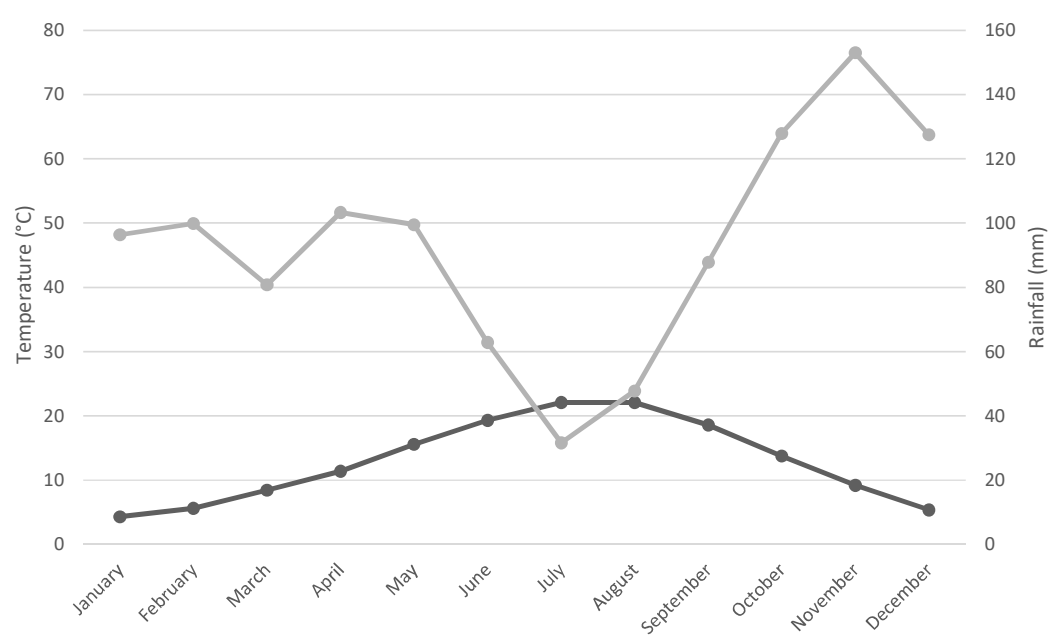

Figure 3. Bagnouls-Gaussen diagram of the study area

The soils belong to unit H4e of the Lazio region Soil Map (Napoli et al., 2019) and, precisely, they are Rendzic Leptosols. These soils, originated from marl and limestone substrate on steep slopes (> 35\%), are very thin and generally thicker from the top to the bottom of the hillslope, as in the case of the investigated area where the soil depth ranges between 10 and $25 \mathrm{~cm}$. Soils tend to be sandier on their surface, and more clayey in the underlying horizons. In the same way, the soil $\mathrm{pH}$ is neutral on the top, and slightly alkaline in depth. Typically, the skeleton is quite abundant, with coarse fragments which are strongly calcareous on the upper level and become lesser calcareous at lower layers. These soils are usually well-drained. The laboratory analysis gave the following average values: $\mathrm{pH}$ from 7.2 to 7.8 ; sand $66.05 \%$; silt $16.025 \%$; clay $17.925 \%$; Total Organic Carbon (TOC) 9.9\%; Soil Organic Matter (SOM) 17.1\%. In such geo-pedological conditions, the soil is preserved only thanks to the forest cover. In case of forest coppicing soil, accelerated erosion occurs and even irreversible deforestation is possible. In that case, re-forestation becomes the unique solution for the vegetation recovery.

Concerning the vegetation type, the forest could be included into Cyclamino hederifolii-Quercetum ilicis. The forest is located on a gradient where Quercus ilex $\mathrm{L}$. and Q. pubescens Willd. tend to cross each other. In particular, these plant communities, present on hills and mountains of Central Apennine, are relic of past hotter climate conditions, so they are quite different from the typical Mediterranean $Q$. ilex forests, lacking the most thermophilic species (Cianfaglione, 2015). Moreover, morphology, spatial structure and dynamics of the studied community are strongly determined by the coppice degenerative or regressive effects (Pedrotti, 2013).

The canopy covers around $85 \%$ of the surface, consisting mainly of $Q$. ilex, with a large participation of Q. pubescens. The canopy composition is completed by Ostrya carpinifolia Scop., some maple species (Acer opalus Mill., A campestre L., A. monspessulanum L.), Fraxinus ornus L., Carpinus orientalis Mill., Juniperus deltoides R.P. Adams, Aria edulis (Willd.) M.Roem. and Ilex aquifolium L., this last with sporadic individuals. Plant species nomenclature follows the "Plants of the World" Kew Science database (http://powo.science.kew.org/) and syntaxonomical nomenclature follows the prodrome of the vegetation of Italy (http://www.prodromo-vegetazione-italia.org). Trees have a maximum age of about thirty years, approximately. Their average diameter is $8 \mathrm{~cm}$, with maximum diameters equal to $17 \mathrm{~cm}$. The average height of the canopy is $6 \mathrm{~m}$, with a maximum height of dominant trees of about $12 \mathrm{~m}$. The largest trees are mostly Quercus ilex, and they correspond to the standards left during the last cutting. 


\section{Stand structure}

For this research, inside the study site, a $3000 \mathrm{~m}^{2}$ plot $(30 \mathrm{~m}$ according to the contour lines and $100 \mathrm{~m}$ according to the steepest slope direction) has been delimited. The forest canopy covers around $85 \%$ of the plot. Within this plot the plants were distinguished into stumps (with shoots), standards and shoots. Then, species, types, position, and diameters of all the plants were detected. For all the stumps, the number of shoots has been counted and their diameters were measured. Using Lidar data (http://www.pcn.minambiente.it/mattm/visualizzazione-metadati/?keyword=\&rid=\&paged_e=12), the average height of the trees has been first calculated and then validated in the field using a Nikon Forestry Pro hypsometer. Since the crowns of the trees intersect each other, it is impossible to detect the crown area of single trees. So, this value has been estimated by dividing the total canopy area by the number of stems, also taking into account the number of standards with respect to the total number of plants. The results were validated by comparison with some plants of a recently coppiced stand.

\section{Soil erosion calculation}

Erosion has been estimated in four different situations: intact forest (case 1), forest with SSM (case 2), forest with one band of standards (1BSM, case 3), and forest with two bands of standards (2BSM, case 4).

Due to its easy employment, in terms of calculation and reduced requirement of input data (Benavidez et al., 2018), in order to estimate the soil erosion we used the Universal Soil Loss Equation - USLE (Wischmeier and Smith 1978). USLE is one of the most common equation used for erosion amount assessment (Van Der Knijff et al., 1999; Diodato, 2004; Grauso et al., 2015), and is expressed as it follows:

$\mathrm{A}=\mathrm{R} \times \mathrm{K} \times \mathrm{L} \times \mathrm{S} \times \mathrm{C} \times \mathrm{P}$

where:

$A=$ Annual soil erosion ( $\mathrm{t} / \mathrm{ha} /$ year),

$\mathrm{R}=$ Rainfall erosivity factor $\left(\mathrm{MJ} \mathrm{J}^{*} \mathrm{~mm} / \mathrm{ha} / \mathrm{h} /\right.$ year $)$,

$\mathrm{K}=$ Soil erodibility factor $\left(\mathrm{t}^{*} \mathrm{~h} / \mathrm{MJ} / \mathrm{mm}\right)$,

$\mathrm{L}=$ Length factor $(-)$,

$S=$ Slope factor $(-)$,

$\mathrm{C}=$ Soil coverage factor $(-)$,

$\mathrm{P}=$ Erosion control measures factor $(-)$.

The $\mathrm{R}$ factor for a given considered period is obtained by summing, for each rainstorm, the product of total storm energy (E), expressed in $\mathrm{MJ} / \mathrm{ha}$, and the maximum 30-minute intensity $\left(\mathrm{I}_{30}\right)$, expressed in $\mathrm{mm} / \mathrm{min}$, (Van Der Knijff et al., 1999). Because of the difficulty to get such high-resolution data, during the years several empirical formulas have been proposed as alternative, aiming to express $\mathrm{R}$ factor using monthly or annual cumulative rainfall values. Among them, we adopted the Torri formula (Torri et al., 2006), as expressed below:

$\mathrm{R}=(3.08 \times \mathrm{P})-944$

With $\mathrm{P}=$ total annual rainfall $(\mathrm{mm})$.

It is noteworthy that more accurate estimations could be obtained using the formulas based on the six hours rainfall amount with 2 years return period. Previous eq. (2) has been chosen because of its simplicity and because it has been developed for the Italian climate. The total annual rainfall has been calculated thanks to the data collected from the Colli sul Velino raingauge station.

The $\mathrm{K}$ factor is soil erodibility factor. It takes into account the soil properties during a rainfall event, and it has been retrieved, starting from the soil analysis of the study area, with KUERY 1.5 software (Borselli et al., 2012). The software uses an algorithm that calculates $K$ factor values: after having defined the climate type and the rock fragment volume, it is possible to calculate $\mathrm{K}$ factor value from the basic information of the soil analysis (percentages of loam, sand, clay, and organic material).

$\mathrm{L}$ and $\mathrm{S}$ factors measure the influence of the topography on the soil erosion. Longer and steeper is the hillside, higher is the erosion. L and S Factors were assessed using the Morgan formula (Morgan 2001). 


$$
\begin{aligned}
& L S=L x S=\left(\frac{l}{22}\right)^{0.5}\left(0.065+0.045 s+0.0065 s^{2}\right) \\
& L=\left(\frac{l}{22}\right)^{0.5} \\
& S=\left(0.065+0.045 s+0.0065 s^{2}\right)
\end{aligned}
$$

Where $l$ is the runoff length (m) and $s$ is the hillside slope (\%). Slope data were taken from slope Lidar map of the study area.

C factor is related to the capacity of vegetation cover to mitigate soil erosion. In this study, we used, respectively, data from Wischmeier and Smith Manual (Wischmeier and Smith, 1978) to asses C factor in a "not disturbed forest" situation (trees inside the study area has an average age of 30 years) and in a "just logged forest" situation (forest with a $20-40 \%$ canopy cover). Although there are different and more sophisticated methods to calculate C factor such as using NDVI or Corine Land Cover, for this theoretical model we preferred to adopt the original Wischmeier and Smith formulation, because of its simplicity and its wide use.

Finally, P factor is related to the cultural practices aiming to reduce the soil erosion. Since in forestry this factor is typically not used, we used P factor equal to 1 as mentioned in the Wischmeier and Smith Manual (Wischmeier and Smith, 1978) even if it is possible that our practice can have also an effect on this factor, but this is impossible to check until field studies will progress.

\section{Results}

\section{Stand structure and bands design}

As results from the field surveys, 424 plants were counted: 383 stumps with 3-4 shoots each and 41 standards. All the results are reported in Table 1.

The Forest Management Plan of the Rieti Municipality, having jurisdiction over the study area, imposes to preserve 90 standards per hectare at the end of each rotation. One third of these trees should have an age equal to or greater than twice the rotation period that is 24 years. So, this is the number of trees to be counted in order to build the bands. Considering the plot of $3000 \mathrm{~m}^{2}$, after the cutting there should be 27 standards, 9 of them with an age equal to twice the rotation. Multiplying the number of plants by their crown areas it has been found out that they should occupy $156 \mathrm{~m}^{2}$. Therefore, inside the plot it would be possible to make one $150 \mathrm{~m}^{2}$ band, $5 \mathrm{~m}$ long according to the steepest slope direction, $30 \mathrm{~m}$ large according to the contour lines, and distant $50 \mathrm{~m}$ from the next band upward and downward according to the steepest slope direction. As an alternative, it would be possible to make two bands having $2.5 \mathrm{~m}$ long in the steepest slope direction, $30 \mathrm{~m}$ large according to the contour lines, and distant $33 \mathrm{~m}$ each one in the steepest slope direction. Figure 4 shows the theoretical map of the plot in the four mentioned cases where the larger and thicker circles represent the standards. Regarding 1BSM (case 3), the band was put in the middle of the plot $(50 \mathrm{~m}$ far from upper and lower sides), meanwhile for 2BSM (case 4) the plot was divided in three zones, putting the two bands at 33 and $66 \mathrm{~m}$ from uphill.

Table 1. Case study field survey results

\begin{tabular}{|l|c|c|c|c|}
\hline & Stumps & Shoots & Standards & Stems \\
\hline $\mathrm{N}$ & 383 & 1693 & 41 & 1734 \\
\hline $\mathrm{N} /$ ha & 1283 & 5643 & 137 & 5780 \\
\hline $\mathrm{N} /$ stump & - & 4.42 & - & - \\
\hline Diameter $(\mathrm{cm})$ & - & 6.72 & 17 & 7 \\
\hline Height $(\mathrm{cm})$ & - & 6.1 & 9.2 & - \\
\hline Crown area $\left(\mathrm{m}^{2}\right)$ & - & 9688 & 372 & 10061 \\
\hline Crown area $/$ tree $\left(\mathrm{m}^{2}\right)$ & - & 5.72 & 9.1 & 5.8 \\
\hline
\end{tabular}




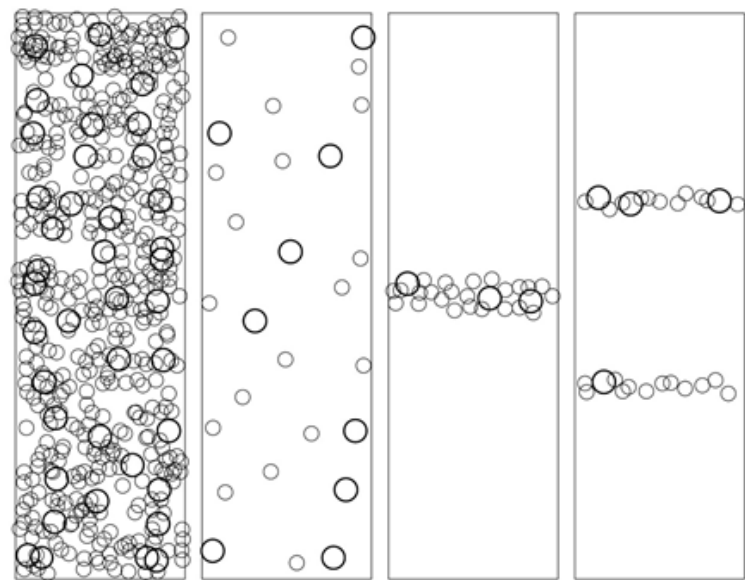

Figure 4. Coppicing methods

From left to right: intact forest (case 1), SSM (case 2), 1BSM (case 3), 2BSM (case 4).

\section{USLE factors values}

\section{$\underline{\mathrm{L} \text { and } S \text { factors }}$}

As we mentioned before, $\mathrm{L}$ and $\mathrm{S}$ factors depend on the runoff length of the study area and on its slope. In case 1 (intact forest), computing $\mathrm{L}$ factor, we considered the length of our area as $100 \mathrm{~m}$, so $\mathrm{L}=2.126$. The same result was also obtained for case 2 (SSM). Since the bands should create a barrier for the surface runoff, regarding case $3(1 \mathrm{BSM})$ and case 4 (2BSM), we choose to consider the length of the study area as $50 \mathrm{~m}$ for case 3 and $33 \mathrm{~m}$ for case 4 . We obtained $L$ factor values of 1.503 for case 3 and of 1.227 for case 4 . The investigated study area has an average slope equal to $72 \%$, and since the silvicultural operation will not affect the slope of the hillside, the $S$ factor value does not change for all the cases. The obtained value is equal to 37.

\section{$\underline{C \text { factor }}$}

$\mathrm{C}$ factor is one of the most variable factors in the USLE equation. It depends on the land use and on the land cover. In forestry environment $\mathrm{C}$ factor depends on the forest type, canopy, and stage (age). For our study we choose to use $\mathrm{C}$ factor values related to mature dense forest for case 1 , while for all the other cases we assumed C factor values related to forest with $20 \%$ of area covered by canopy. So, for case 1 we used the $\mathrm{C}$ value of 0.0005 and for the other cases a $C$ value of 0.009 (Wischmeier and Smith 1978). As aforementioned, for the $C$ values estimation we used the USLE original tables.

\section{$\mathrm{K}$ factor and $\mathrm{R}$ factor}

$\mathrm{K}$ and $\mathrm{R}$ factors do not change depending on the coppicing methods because they refer to soil and rainfall. They are respectively equal to $0.016 \mathrm{t}^{*} \mathrm{~h} / \mathrm{MJ} / \mathrm{mm}$ for $\mathrm{K}$, and $2533.7 \mathrm{MJ}^{*} \mathrm{~mm} / \mathrm{ha} / \mathrm{h} /$ year for $\mathrm{R}$.

\section{P factor}

As it was mentioned before we set a $P$ factor value equal to 1 for each study case.

Applying the USLE equation, we got an annual average soil erosion value of $1.6 \mathrm{t}^{*} \mathrm{ha}^{-1 *} \mathrm{y}^{-1}$ for case 1 , a value of $28.9 \mathrm{t}^{*} \mathrm{ha}^{-1 *} \mathrm{y}^{-1}$ for case 2 (SSM), a value of $20.4 \mathrm{t}^{*} \mathrm{ha}^{-1 *} \mathrm{y}^{-1}$ for case 3 (1BSM) and finally a value of 16.7 $\mathrm{t}^{*} \mathrm{ha}^{-1 *} \mathrm{y}^{-1}$ for case 4 (2BSM) (Table 2). Figure 5 offers an immediate information about the influence that the coppicing method has on the soil erosion. As we can observe from Table 2 and from Figure 5 a every time that a forest is logged, independently from the chosen silvicultural method, the soil erosion rate strongly increases. Indeed, the soil erosion increase is about $1718 \%$ between case 1 and 2 , about $1186 \%$ between case 1 and 3 and, finally, about $950 \%$ between case 1 and 4 (Table 3, Figure 5b). 
Concluding, we calculate the soil erosion reduction percentage between the traditional coppicing method (SSM) and the proposed methods (1BSM, 2BSM). The soil erosion rate reduction between SSM and $1 \mathrm{BSM}$ is $29 \%$, while between SSM and 2BSM is $42 \%$ (Table 3, Figure 5c).

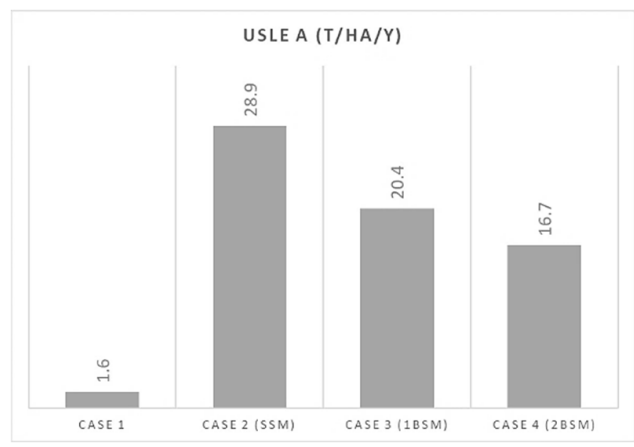

(A)

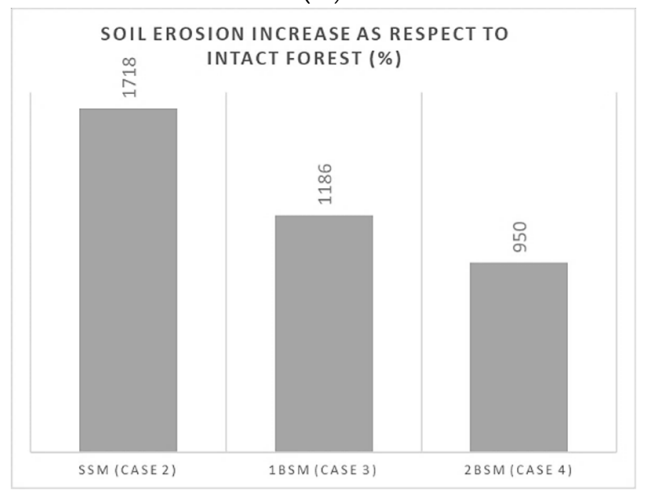

(B)

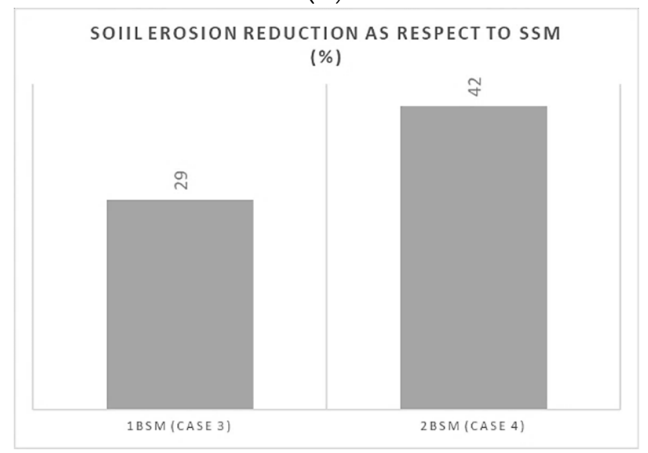

(C)

Figure 5. (A) Annual soil erosion; (B) percentage increases of soil erosion for cases 2-3-4 as respect to case 1 (intact forest); (C) percentage decreases of soil erosion for cases 3-4 as respect to case 2 (SSM)

\section{Discussion}

In Italy, the relationship between silviculture and soil erosion has not been fully explored up to now. Even the guidelines for the evaluation and the mitigation of hydrogeological risk, published by ISPRA (the Italian national institute for protection and research of the environment), are extremely scarce in the topic (Bazzoffi et al., 2013). As concerns the coppice with standards, comparisons on the amount of soil erosion associated with the traditional SSM and more recent GSM have not even been performed. 
Table 2. USLE calculation results

\begin{tabular}{|c|c|c|c|c|}
\hline & $\begin{array}{l}\text { USLE factors values, } \\
\text { intact forest (Case 1) }\end{array}$ & $\begin{array}{l}\text { USLE factors values, } \\
\text { SSM (Case 2) }\end{array}$ & $\begin{array}{l}\text { USLE factors values, } \\
\text { 1BSM (Case 3) }\end{array}$ & $\begin{array}{l}\text { USLE factors values, } \\
\text { 2BSM (Case 4) }\end{array}$ \\
\hline L Factor & \multicolumn{2}{|c|}{213} & 1.5 & 1.23 \\
\hline S Factor & \multicolumn{4}{|c|}{37} \\
\hline C Factor & 0.0005 & \multicolumn{3}{|c|}{0.009} \\
\hline K Factor & \multicolumn{4}{|c|}{0.016} \\
\hline P Factor & \multicolumn{4}{|c|}{1} \\
\hline R Factor & \multicolumn{4}{|c|}{2533.70} \\
\hline USLE A (t/ha/y) & 1.6 & 28.9 & 20.4 & 16.7 \\
\hline
\end{tabular}

Table 3. Variations in soil erosion due to the proposed coppicing methods

\begin{tabular}{|l|c|c|c|}
\hline & SSM (Case 2) & 1 BSM (Case 3) & 2 BSM (Case 4) \\
\hline $\begin{array}{l}\text { Annual mean soil } \\
\text { erosion(t/ha/y) }\end{array}$ & 28.9 & 20.4 & 16.7 \\
\hline $\begin{array}{l}\text { Soil erosion increase as } \\
\text { respect to intact forest (\%) }\end{array}$ & 1718 & 1186 & 950 \\
\hline $\begin{array}{l}\text { Soil erosion reduction as } \\
\text { respect to SSM (\%) }\end{array}$ & - & 29 & 42 \\
\hline
\end{tabular}

Regarding the method here proposed (BSM), it is important to say that, in the past, there were few scientific articles (characterized by a limited diffusion) that proposed to leave the standards in stripes along the contour lines (Del Favero, 2001; Bernetti and La Marca, 2010). Such articles refer to the possibility of using this method only for the reduction of the damages due to rocks falling after a cutting, circumstance that indeed the stripes of standards could avoid or mitigate. Unfortunately, none of the aforementioned works regards soil erosion neither tries to calculate the amount of soil erosion as a result of this type of arrangement.

However, the results of our conceptual model seem to confirm the validity of this approach and justify the field experiments, in order to verify the theoretical model. In fact, the reduction of erosion in the examined investigated area varies from $29 \%$ to $42 \%$ depending on the number of bands left on the field. It is important to mention also that the method presented here acts, substantially, only in the Factor L, diminishing the length of the hillslope that is exposed to the erosive process.

In addition, $C$ Factor has its impact on the reduction of soil erosion, that here we did not calculate. It is evident that if trees are not present on the ground, the rainfall can directly fall on the soil surface creating soil erosion. In a forest, the $\mathrm{C}$ factor can be approximated with the capacity that the trees have, thanks to their canopies and ground cover (litter, organic residues etc.), to absorb the rainfall impact and to diminish the splash effect. Regarding $C$ Factor, with the theoretical method that we used, it was impossible to distinguish between the two types of cutting (SSM or BSM), because of the same number of trees left, with same age and same canopy. This is the reason why the $\mathrm{C}$ factor has the same value in both cases. It is clear that a forest canopy formed by the intersection of multiple tree crowns, as in BSM, even if it consists in the same number of elements with equal dimensions, will intercept a bigger rainfall volume in comparison with the sum of the single crowns of the scattered trees. Moreover, in this model, we are aiming to implement another practical solution that will help reducing soil erosion. When a coppice logging is carried out, after the extraction of tree trunks, typically, forest workers leave bundles of twigs in windrows along the steepest slope direction because this disposition is easier for their work. This material can be left in site for a natural degradation, sometimes enhancing the risk of forest fires, or it can be removed or chipped.

If such material would be placed near the bands of standards, following the contour lines, a natural weir would be created, creating a natural barrier to overland flow, limiting the soil erosion and enhancing the growth 
of new plants. This was demonstrated inside Majella National Park, using wood barriers inside pine-beech forest (Figure 6).

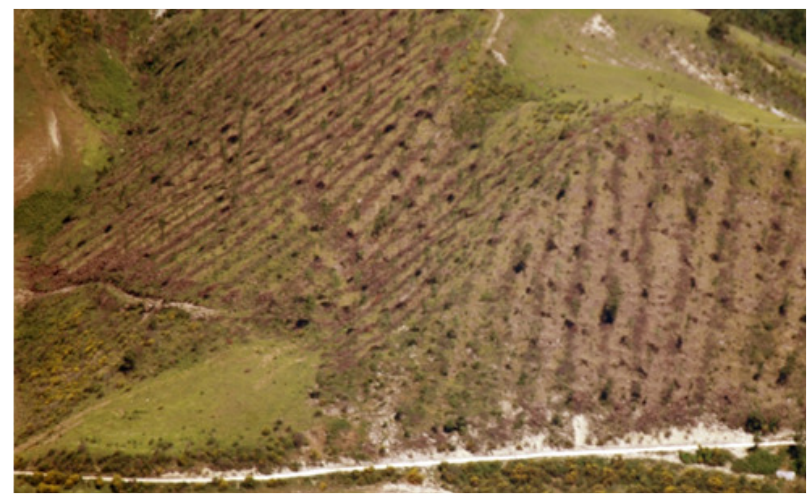

(A)

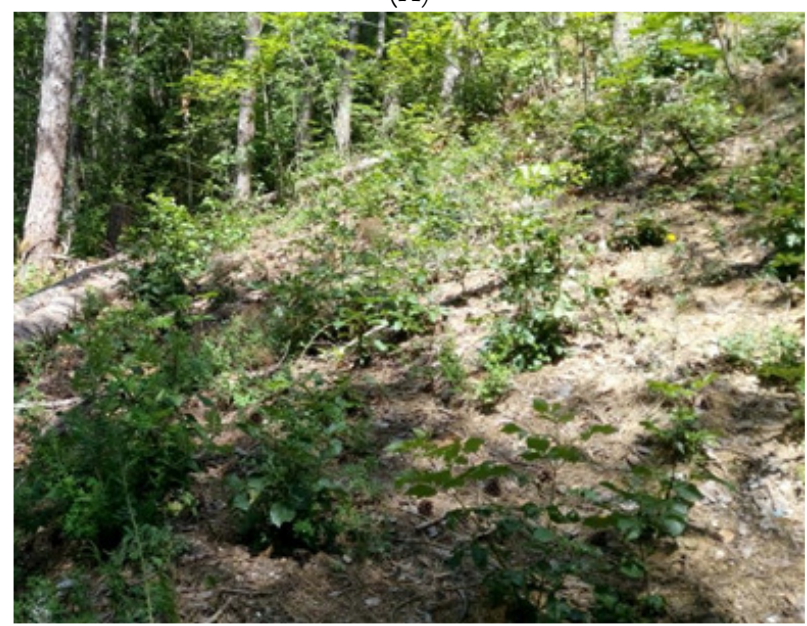

(B)

Figure 6. Examples of coppice with bundles of twigs in windrows and natural regeneration by seed (A) Coppice with bundles of twigs in windrows along the steepest slope direction; (B) Natural regeneration by seed along a $\log$ weir

In any case, leaving unaltered the number and the type of standards and changing only their positioning inside the logged area, the BSM will not affect the wood extraction. In fact, every forest operation (logging and extraction) would not be complicated.

In addition, this silvicultural operation would bring other numerous ecological, technical, and economical advantages. On the ecological point of view, there would be a significant reduction on the loss of biodiversity, both vegetal and animal. Because of the wide exposure of the bare soil, every time that a coppice is logged with the traditional SSM, the conservation of nemoral flora, linked to a more evolved forest succession, is irreparably lost. The plant community regresses towards the pioneer stages and the vegetation cycle starts again from zero. Some species could also definitely disappear. Baragatti et al. (2002; 2004) compared the composition of the flora and the vegetation dynamics inside different Turkey oak (Quercus cerris $\mathrm{L}$.) coppices with different typologies and densities of SA: with no standards, with a limited number of scattered standards ( 50 plants/ha), with a high number of scattered standards ( 140 plants/ha) and, finally, with standard disposed in groups (GSM). The results of the study showed that the coppice with GSM is the one that can assure both the greater floristic and vegetational diversity and the conservation of all the nemoral species, thus confirming even for the coppice the Peterken (1999) models on the relationships between forest area size and biodiversity. 
In our proposed method, leaving unaltered the floristic composition of the stripes, so that they can be considered as small groups, the result should be similar.

The perspective for the fauna component is not different. Most of vertebrate or invertebrate animals can continue to find shelter and refuge (home, alimentation, and reproduction) inside and along the standard stripes where the vegetation is still undisturbed. With reference to Italian coppices, this has been demonstrated using GSM by Capizzi and Luiselli (1996) for rodents, and by Battisti and Marini (2018) for the ornithofauna, that seems to be particularly sensible to the forests changing, both in species richness and in individual numbers. As concerns the invertebrates, many insects' species benefit from the forest cutting thanks to the pioneer herbaceous flora that grows in the soil with no trees, but, on the other hand, there will be less species related to the mature stage of the forest (Greatorex-Davies and Marrs, 1992; Buckley and Mills, 2018). The coppice with BSM allows the creation of habitats useful to the conservation and the increase of biodiversity in both senses. Finally, the bands of standards permit the conservation of the biotic component that lives in the soil (fungi, bacteria, nematodes, and so on) that for long time has not been considered but nowadays it has been proved to be essential for the entire life on planet, which it is revealing more and more its symbiotic nature (Sheldrake, 2020).

The BSM, in comparison with SSM and GSM, can work exactly as an ecological corridor that crosses the logged surface and connects the undisturbed parts of the forest. In this way, it guarantees the continuity of animal movement inside the forest and the vegetal species gene flux (Battisti and Romano, 2007).

Moreover, this silvicultural model improves the forest natural regeneration by seed because the shadow of adult trees reduces the competition between pioneer herbaceous plants and seedlings and improves the natural processes of seedling mycorrhization (Figure 6b).

Another positive effect of BSM is given by the reduction of the wind effect. Plants in group can better withstand the wind (and snow) pressure and they can protect from the wind action the young suckers and shoots. The BSM, in fact, constitute real windbreaks, able to reduce the wind speed and therefore the damages that it can produce, both directly, as mechanical damages, and indirectly, through the increase of evapotranspiration in countries with drier climate (Cleugh, 1998).

Forests have an ecological role on the planet that is often overlooked or underestimated. We refer to the production of liquid water through the interception of droplets of condensed water vapour contained in the air (Sheil 2009, 2014; Ellison et al., 2017; Jarimi et al., 2020;). The intensity of such process depends on the site characteristics, but it is also proportional with the density of trees, their height, and their position. For these reasons, the BSM, in addiction to acting as a windbreak, can increase the capacity to capture atmospheric water that will improve the water availability in the coppice stand and consequently the soil fertility. This process can be crucial in the future considering the climate change context and an always more frequent aridity.

In addition, at silvicultural level, the BSM could offer many advantages. Shoots which resprout from the stumps after the cutting would not suffer the shadow created by the standards (the shadow is concentrated only along the stripes) so that their volume increase would be higher and faster. In such circumstance the foresters could avoid searching compromises on the number of standards per hectare, circumstance that up to now has not unique solution (La Marca 1991). Eventually there should be evaluation only for the sciaphilous species, but in this case some standards could also be left scattered in the logged surface to permit a better shadowing for that kind of plants. Conversely, the reciprocal proximity of the standards inside the bands will create conditions of major competition for the sunlight encouraging a higher and straighter height growth of the stems. For the same reason, in the stems we will observe a lower number of knots and in general less flaws so that a better technological quality and a resulting greater economic value could be retrieved (Bernetti et al., 2012).

This model will also help the conversion from coppice to high forest, as it happens in mixed conversion systems. The conversion could proceed on both sides of the bands and could interest the edges of the forest that are connected by the stripes, proceeding in concentric polygons. This solution belongs to forest restoration approaches in which the width of the bands, or in general the size of the areas covered by trees, is proportional 
to the success of the operations (Londe et al., 2021). Lastly, this approach could foster the new proposal about the so called "tree-oriented silviculture" (Bastien and Wilhelm, 2000; 2003; Manetti et al., 2016).

Moreover, the bands hide better the view of the bare areas simulating a seamless covering of the slopes with a real improvement at the landscape level. Indeed, the reduction of the impact on the landscape is one of the reasons why some authors (ODARC, 2004; Fiorucci, 2009) are trying to promote the diffusion of GSM coppice instead of the traditional approach (SSM).

Finally, a particular case is represented by forest fires that are often followed by significant erosive phenomena on the steepest sides of mountains (Coschignano et al., 2019). Usually, a typical practice to limit soil erosion after fires is creating fascines along the contour lines. The stripes of standards, even if the upper part of the plant is burned, are living fascines that can ensure a greater soil retention and a better plants recovery or regeneration after a potential fire. They can therefore be effective against accelerated and extended erosive phenomena by reducing the risk coefficient and the need for emergency actions.

\section{Conclusions}

The coppice system with bands of standards (BSM), here presented, is very simple and the first simulation seems to be encouraging. It consists of leaving standards stripes perpendicular to the steepest slope direction, instead of the scattered ones all over the area, in order to make a barrier for surface runoff. Application of USLE equation showed that with respect to the standard scattered method (SSM), the BSM is able to reduce soil erosion amount in the range $29 \%-42 \%$.

It must be underlined that this model can be assimilated to a clear-cut on small surfaces logging method (Perrin, 1954; Bernetti et al., 2012), and it is exactly like this. It is a simple coppice on small areas represented by the division of a large surface using a certain number of stripes of trees drawn along the hillslope contour lines, with the aim for the stripes to absorb all the runoff coming from the upper coppiced area. In some cases, this model could be a variation of the strip shelterwood system that is a silvicultural method in which cutting surfaces are alternated with untreated ones. The BSM, anyway, reflects the proposal of Buckley et al. (2018), and of the references cited therein, that on steeper terrain always recommend logging on very small surfaces, not wider than 0.5 ha.

The model was here presented and discussed from a theoretical point of view, and in the further step of the research, the effectiveness of the proposed system will be validated through field experiments keeping into account different environments and species. In particular, the best geometric layout of standards that may include linear bands, sinuous, discontinuous, alternate in groups, and so on will be investigated. The core of the experimental field campaign will be to assess whether these bands are able to absorb all the runoff coming from the upper coppiced area, confirming or not the theoretical model.

In order to avoid the not negligible damage caused by soil erosion, the introduction of bands of standards system can be an effective method to reduce drawbacks, conserve nemoral biodiversity and encourage forest restoration.

\section{Authors' Contributions}

Conceptualization: BS, TA, AP; Data curation: PS, AP; Formal analysis: PS, AP; Funding acquisition: BS, MP; Investigation: BS, PS, KC, MP; AP; Methodology: BS, PS, AP; Project administration: BS; Software: PS; Supervision: BS, AP; Writing - original draft: BS, PS, KC, MP, AP; Writing - review and editing: PS, FV. All authors read and approved the final manuscript. 


\section{Acknowledgements}

This research has been financed by the Department for Regional Affairs and Autonomies (DARA), Presidency of the Council of Ministers, Rome. Number of Grant DARA-DAFNE 40506.

We thank the Municipality of Rieti for having granted a parcel of its forest property to carry out the research.

\section{Conflict of Interests}

The authors declare that there are no conflicts of interest related to this article.

\section{References}

Altieri V, De Franco S, Lombardi F, Marziliano PA, Menguzzato G, Porto P (2018). The role of silvicultural systems and forest types in preventing soil erosion processes in mountain forests: a methodological approach using cesium137 measurements. Journal of Soils Sediments 18(12):3378-3387. https://doi.org/10.1007/s11368-018-19578

Amanti M, Pecci M (1995). Proposta di una scheda per la raccolta e l'informatizzazione dei dati utili alla classificazione e caratterizzazione degli ammassi rocciosi. [Proposal for the creation of a database for the collection and computerisation of data for the classification and characterisation of rock masses]. Atti IV Convegno dei giovani ricercatori in geologia applicata, Riccione, Quaderni di geologia applicata, 1, 1-8, Pitagora Editrice, Bologna, Italy.

Amorini E, Bruschini S, Cutini A, Di Lorenzo MG, Fabbio G (1998). Intensity of standard release and shoots dynamics in a Turkey oak (Quercus cerris L.) coppicies. First contribution. Annali Istituto Sperimentale Selvicoltura Arezzo 27(1996):105-111.

Baragatti E, Frati L, Chiarucci A (2002-2004). Cambiamenti nella diversità della vegetazione in seguito a diversi tipi di matricinatura in boschi di cerro. [Changes in vegetation diversity as a result of different types of coppicing in turkey oak forests]. Annali Istitituto Sperimentale Selvicoltura 33:39-50.

Bastien Y, Wilhelm GJ (2000). Une sylviculture d'arbres pour produire des gros bois de qualité. [A tree silviculture to produce high quality wood]. Revue Forestière Française 5:407-424.

Bastien Y, Wilhelm GJ (2003). Selvicoltura d'albero: un approccio per la produzione di legname con buone caratteristiche e di grandi dimensioni. [Tree silviculture: an approach to produce good quality and dimension wood]. Sherwood-Foreste e Alberi Oggi 86:5-13.

Battisti C, Marini F (2018). Structural changes in bird communities before and after coppice management practices: a comparison using a diversity/dominance approach. Israel Journal of Ecology and Evolution 64:16-24. https://doi.org/10.1163/22244662-20181033

Battisti C, Romano B (2007). Frammentazione e connettività. Dall'analisi ecologica alla pianificazione ambientale. [Fragmentation and connectivity. From the ecological analysis to the environmental planification]. Città Studi Edizioni, Torino, pp 467.

Bazzoffi P, Ciccarese L, De Meo A, Di Leginio M, Fumanti F, Guerra P, ... Trigila A (2013). Linee guida per la valutazione del dissesto idrogeologico e la sua mitigazione attraverso misure e interventi in campo agricolo e forestale. [Guidelines for the evaluation of the Hydrogeological risk and its mitigation trough measures and intervention in agriculture and forest field]. ISPRA. Manuali e Linee Guida 85/2013.

Benavidez R, Jackson B, Maxwell D, Norton K (2018). A review of the (Revised) Universal Soil Loss Equation ((R)USLE): With a view to increasing its global applicability and improving soil loss estimates. Hydrology and Earth System Sciences 22(11):6059-6086. https://doi.org/10.5194/hess-22-6059-2018

Bernetti G, Del Favero R, Pividori M (2012). Selvicoltura produttiva. Manuale pratico. [Productive silviculture. Practice manual]. Edagricole, Bologna, pp 225.

Bernetti G, La Marca O (2010). Il bosco ceduo nella realtà italiana. [Coppice forest in the italian reality]. Lettura tenuta il 21 ottobre 2010. Atti dei Georgofili, pp 44 . 
Bianchi L, Giovannini G (2006). Observations on the felling of standards in oak coppices, Central Italy. Forest 3(3):397406. https://doi.org/10.3832/efor0390-0030397

Bieniawski ZT (1976). Rock mass classification in rock engineering. Proceedings Symposium Exploration for Rock Engineering. Johannesburg. Balkema 1:97-106.

Borrelli P, Panagos P, Märker M, Modugno S, Schütt B (2017a). Assessment of the impacts of clear-cutting on soil loss by water erosion in Italian forests: First comprehensive monitoring and modelling approach. Catena 149:770-781. https://doi.org/10.1016/j.catena.2016.02.017

Borrelli P, Robinson DA, Fleischer LR, Lugato E, Ballabio C, Alewell C, ... Panagos P (2017b). An assessment of the global impact of 21st century land use change on soil erosion. Nature Communications 8(1):2013. https://doi.org/10.1038/s41467-017-02142-7

Borselli L, Torri D, Poesen J, Iaquinta P (2012) A robust algorithm for estimating soil erodibility in different climates. Catena 97:85-94. https://doi.org/10.1016/j.catena.2012.05.012

Bottacci A (2018). Il TUFF, la gestione attiva dei boschi e le generazioni future. [TUFF, active forest management and future generations]. Italia Forestale e Montana 73:4-5.

Buckley P, Mills J (2018). Conservation of Coppice and High Forest Management within the Natura 2000 Network - A Review. Chapter 4. In: Unrau A, Becker G, Spinelli R, Lazdina D, Magagnotti N, Nicolescu VN, Buckley P, Bartlett D, Kofman PD (Eds). Coppice Forests in Europe. Albert Ludwig University of Freiburg, pp 110-135.

Buckley P, Suchomel C, Moos C, Conedera M (2018). Prevention of Soil Erosion and Rockfall by Coppice and High Forest - A Review. Chapter 4. In: Unrau A, Becker G, Spinelli R, Lazdina D, Magagnotti N, Nicolescu VN, Buckley P, Bartlett D, Kofman PD (Eds). Coppice Forests in Europe. Albert Ludwig University of Freiburg, pp 139-151.

Capizzi D, Luiselli L (1996). Ecological relationships between small mammals and age of coppice in an oak-mixed forest in central Italy. Revue d'Écologie 51:277-291.

Ceccherini G, Duveiller G, Grassi G, Lemoine G, Avitabile V, Pilli R, Cescatti A (2020). Abrupt increase in harvested forest area over Europe after 2015. Nature 583:72-77. https://doi.org/10.1038/s41586-020-2438-y

Cianfaglione K (2015). On the potential of Quercus pubescens Willd. and other species of Quercus in the Camerino syncline (Central Italy). In: Box EO and Fujiwara K (Eds). Warm-temperate Deciduous Forests Around the Northern Hemisphere. Geobotany Studies. Basics, Methods and Case Studies. Springer Nature, Switzerland, pp 165-174. https://doi.org/10.1007/978-3-319-01261-2_9

Clauser F (1989). Povertà del bosco ceduo. [Poverty of coppice forest]. In: Biondi E (Ed). Il Bosco nell'Appennino: 8398. Centro Studi Valleremita, Fabriano.

Cleugh HA (1998). Effects of windbreaks on airflow, microclimates and crop yields. Agroforest Systems 41:55-84.

Corona $\mathrm{P}$, La Marca O, Schirone $\mathrm{B}$ (1986). Ricerche sull'ottimizzazione della intensità di matricinatura nei cedui di cerro: I - Il ceduo composto a maturità. [Research on the optimization of the intensity of the release of standards in turkey oak coppice: I-mature mixed coppice]. Annali Accademia Italiana Scienze Forestali 35:123-158.

Coschignano G, Nicolaci A, Ferrari E, Cruscomagno F, Iovino F (2019) Evaluation of hydrological and erosive effects at the basin scale in relation to the severity of forest fires. iForest-Biogeosciences and Forestry 12:427-434. https://doi.org/10.3832/ifor2878-012

Del Favero R (2001). Progetto Boschi del Parco Regionale dei Colli Euganei. [Project Forests of the Colli Euganei regional park]. Progetto Leader II - G.A.I. Patavino. Parco Regionale dei Colli euganei, Este (Padova).

Desiato F, Fioravanti G, Fraschetti P, Perconti W, Piervitali E (2015). Il Clima Futuro in Italia: Analisi delle proiezioni dei modelli regionali. [Future Climate in Italy: Analysis of the projections of regional model]. Edizione 2015. ISPRA, Stato dell'Ambiente 58/2015.

Di Fernando S, Marchetti A, Migliore M, Napoli R, Paolanti M, Pennelli B (2019). Atlante dei Suoli della Regione Lazio. [Latium region Atlas of soils]. Arsial, Regione Lazio, ISBN 978-88-904841-2-4.

Diodato N (2004). Estimating RUSLE's rainfall factor in the part of Italy with a Mediterranean rainfall regime. Hydrology and Earth System Sciences 8(1):103-107. https://doi.org/10.5194/hess-8-103-2004

EEA - European Environment Agency (2017). Climate Change Adaptation and Disaster Risk Reduction in Europe. EEA: Kongens Nytorv, Denmark 15:1-171.

Ellison D, Morris CE, Locatelli B, Sheil D, Cohen J, Murdiyarso D, ... Sullivan CA (2017). Trees, forests, and water: Cool insights for a hot world. Global Environmental Change 43:51-61. https://doi.org/10.1016/j.gloenvcha.2017.01.002 
Schirone B et al. (2021). Not Bot Horti Agrobo 49(2):12325

Eurostat-European Statistical Office (2020). Eurostat. Retrieved 2021 February 14 from https://ec.europa.eu/eurostat/web/energy/data/energy-balances

Fiorucci E (2009) Le matricine nei boschi cedui: le attuali regole di rilascio sono ancora valide? [Standards in coppice forests: current rules are still valid?]. Forest@-Journal of Silviculture and Forest Ecology 6:56-65.

Garfi G, Veltri A, Callegari G, Iovino F (2006). Effetti della ceduazione sulle perdite di suolo in popolamenti di castagno della Catena Costiera Cosentina (Calabria). [Effect on the soil loss after coppicing in chestnut populations of the Cosentino Coast Chain (Calabria)]. L'Italia Forestale e Montana 6:507-531.

Grauso S, Verrubbi V, Zini A, Peloso A, Crovato C, Sciortino M (2015). Soil Erosion Estimate in Southern Latium (Central Italy) Using Rusle and Geostatistical Techniques. ENEA Technical Reports, RT/2015/22/ENEA.

Greatorex-Davies JN, Marrs RH (1992). The quality of coppice woods as habitats for invertebrates. In: Buckley GP (Ed). Ecology and Management of Coppice Woodlands. Springer, Dordrecht, pp 271-296.

Grohmann F, Savini P, Frattegiani M (2002). La matricinatura per gruppi. [Grouped Standards method]. Sherwood $80: 25-29$.

Iovino F (2007). Analisi dell'uso del suolo e linee operative di gestione forestale sostenibile per mitigare la vulnerabilità del territorio di Pizzo d'Alvano (Campania). [Use of soil analysis and operative guidelines for a sustainable forest management in Pizzo D’Alvano area (Campania)]. Quaderni del Laboratorio di Cartografia Ambientale e Modellistica Idrogeologica, Università della Calabria, Dipartimento Difesa del Suolo. Volume 2, pp 64.

Iovino F (2009). Ruolo della selvicoltura nella conservazione del suolo. [Silviculture role on the conservation of soil]. In: Atti del Terzo Congresso Nazionale di Selvicoltura (Taormina, 16-19 Ottobre 2008). Accademia Italiana di Scienze Forestali, Firenze, pp 425-436.

Jarimi H, Powell R, Riffat S (2020). Review of sustainable methods for atmospheric water harvesting. International Journal of Low-Carbon Technologies 15(2):253-276. https://doi.org/10.1093/ijlct/ctz072

La Marca O (1991). Studi e ricerche sull'ottimizzazione della matricinatura nei boschi cedui. [Study and research on the optimization of the release of standards in coppice forest]. Italia Forestale e Montana 2:118-132.

La Marca O, Marzialiano PA, Scotti R (1996). Effect of standard density on coppice structure development: evaluation 14 year after coppicing in a Turkey oak experimental trial. Annali Istituto Sperimentale Selvicololtura, Arezzo 27:161-166.

La Marca O, Mattioli M, Iorio G (1987). Ricerche sull'ottimizzazione della intensità di matricinatura nei cedui di cerro: II - Il soprassuolo arboreo nei primi due anni del ciclo produttivo. [Research on the optimization of the intensity of the release of standards in turkey oak coppice: The tree stand in the first two years of the production cycle]. Annali Accademia Italiana Scienze Forestali 36:3-33.

Londe V, Messias TBMC, Caldas de Sousa H (2021). Vegetation restoration is associated with increasing forest width. New Forests 52:129-144. https://doi.org/10.1007/s11056-020-09786-2

Manetti MC, Becagli C, Sansone D, Pelleri F (2016). Tree-oriented silviculture: a new approach for coppice stands. iForest-Biogeosciences and Forestry 9:791-800. https://doi.org/10.3832/ifor1827-009

Morgan RPC (2001). A simple approach to soil loss prediction: A revised Morgan-Morgan-Finney model. Catena 44(4):305-322. https://doi.org/10.1016/S0341-8162(00)00171-5

ODARC (2004). Guide pratique pour l'exploitation des forêts de chêne vert en Corse. [Practical guide for the exploitation of the holm oak forests in Corsica]. Office Développement Agricole Rural de Corse, Bastia, France pp 40.

Pedrotti F (2013). Plant and vegetation mapping. Springer, Dordrecht, pp 249.

Perrin H (1954). Sylviculture. [Silviculture. Ed. Ecole Nationale des Eaux et Forêts. Trad. ital. Selvicoltura, 1986. Accademia Italiana di Scienze Forestali. Firenze.

Peterken GF (1999). Applying natural forestry concepts in a intensively managed landscape. Global Ecology and Biogeography 8:321-328. https://doi.org/10.1046/j.1365-2699.1999.00140.x

Piussi P (2000). Selvicoltura generale. [General silviculture]. UTET, Torino.

Plant of the World http://powo.science.kew.org/

Searchinger TD, Beringer T, Holtsmark B, Kammen DM, Lambin EF, Lucht W, ... van Ypersele JP (2018). Europe's renewable energy directive poised to harm global forests. Nature Communications 9:1-4.

Sheil D (2009). How forests attract rain: an examination of a new hypothesis. BioScience 59:341-347. https://doi.org/10.1525/bio.2009.59.4.12

Sheil D (2014). How plants water our planet: advances and imperatives. Trends in Plant Science 19(4):209-211. https://doi.org/10.1016/j.tplants.2014.01.002 
Sheldrake M (2020). L'ordine nascosto. La vota segreta dei funghi. [How fungi make our worlds, change our minds, and shape our futures]. Marsilio, Venezia.

Torri D, Borselli L, Guzzetti F, Calzolari MC, Bazzoffi P, Ungaro F, Bartolini D, Salvador Sanchis MP (2006). Italy. In: Boardman J and Poesen J (Eds). Soil Erosion in Europe. https://doi.org/10.1002/0470859202.ch20

Trigila A, Iadanza C, Bussettini M, Lastoria B (2018). Dissesto idrogeologico in Italia: pericolosità e indicatori di rischio. [Hydrogeological risk in Italy: Danger and risk indicators]. Edizione 2018. ISPRA, Rapporti 287/2018.

Vacca A, Aru F, Ollesch G (2017). Short-term impact of coppice management on soil in a Quercus ilex L. stand of Sardinia. Land Degradation \& Development 28 (2):553-565. https://doi.org/10.1002/ldr.2551

Van der Knijff JM, Jones RJ, Montanarella L (2000). Soil erosion risk assessment in Italy. European Soil Bureau, Joint Research Center of the European Commission. Scientific-Technical Reports, EUR 19044 EN, pp 34.

Wischmeier WH, Smith DD (1978). Predicting rainfall erosion losses - a guide to conservation planning. USDA, Science and Education Administration.

Zanzi Sulli A, Di Pasquale G (1993). Funzioni delle matricine dei cedui nella teoria selvicolturale del XVIII e XIX secolo. [Standards features in coppice in the silvicultural theory of the XVIII and XIX centuries]. Rivista Storica Agricola 1:109-121.
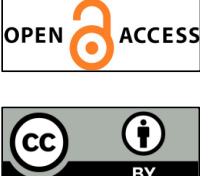

The journal offers free, immediate, and unrestricted access to peer-reviewed research and scholarly work. Users are allowed to read, download, copy, distribute, print, search, or link to the full texts of the articles, or use them for any other lawful purpose, without asking prior permission from the publisher or the author.

License - Articles published in Notulae Botanicae Horti Agrobotanici Cluj-Napoca are Open-Access, distributed under the terms and conditions of the Creative Commons Attribution (CC BY 4.0) License. (c) Articles by the authors; UASVM, Cluj-Napoca, Romania. The journal allows the author(s) to hold the copyright/to retain publishing rights without restriction. 